\title{
Energy Consumption Status and Characteristics Analysis of University Campus Buildings
}

\author{
Y.T. Ma ${ }^{1, a^{*}}$, M.Y. Lü, b J.T. Weng ${ }^{1, c}$ \\ ${ }^{1}$ Room 506, Crescent Building, Zijingang Campus of Zhejiang University, Xihu District, Hangzhou \\ City, Zhejiang Province, China \\ a4412617504@qq.com, ${ }^{b} 709953403 @ q q . c o m,{ }^{c} 815895960 @ q q . c o m$
}

Keywords: University campus building ; Energy consumption status ; Characteristics analysis ; Energy saving measure ; Carbon reduction plan

\begin{abstract}
This paper analyzes the energy status and energy saving measures of the universities in the world based on the current situation of building energy consumption, compares the data including energy consumption per unit area, electric energy consumption per unit area, energy consumption per capita, electric energy consumption per capita and carbon emission per capita. The characteristics of building energy consumption in universities are summarized which can provide the basis for energy saving measures and the development of carbon reduction plan.
\end{abstract}

\section{Introduction}

With the development of higher education, the global university campus construction is in a stable period. According to statistics, energy consumption per capita in university campus and energy consumption per unit area are higher than the energy consumption per unit area of the residential buildings ${ }^{[1]}$. The university building energy efficiency has become an important task of energy efficiency works after the office building and large public building ${ }^{[2]}$. A lot of universities in the world attach great importance to energy efficiency in buildings in campus and campus building energy consumption monitoring. Some universities in Asia, Americas and Europe set up the regulation of energy consumption platform and publish that through various means, such as annual accounting reports, statistical reports, energy consumption monitoring platform.

\section{Energy consumption status of university campus buildings}

On the whole, the differences of the energy consumption in the university campus between the different countries are relatively large.

The average annual energy consumption per unit area of the United States is the largest in the world which is reaching to $490 \mathrm{kWh} / \mathrm{m}^{2}$. In South Korea and Finland, the energy consumption which is $210 \mathrm{kWh} / \mathrm{m}^{2}$ and $229 \mathrm{kWh} / \mathrm{m}^{2}$ is relatively close. Min Hee Chung et al. compare the energy consumption data of 11 buildings for a university in Seoul. The difference of building energy consumption with different types, different years, different building envelope, heating refrigeration equipment is great. The minimum is $106 \mathrm{kWh} / \mathrm{m}^{2}$. The maximum is $399 \mathrm{kWh} / \mathrm{m}^{2}{ }^{[3]}$. Tiina Sekki et al. collect the basic building information of the school in the city of Espoo and compare the building energy consumption data in 2012. The trend of university building's annual energy consumption is obviously decreasing and the differences of the energy consumption in different constructions are large. The annual energy consumption per unit area is between $145 \mathrm{kWh} / \mathrm{m}^{2}$ and $381 \mathrm{kWh} / \mathrm{m}^{2}{ }^{[4]}$.

Parts of the European countries count the heating energy consumption per unit area of the domestic university. It is concluded that the difference of the heating energy consumption is big in Ireland and the United Kingdom of the same latitude but the difference of that is small in Greece and Italy of the same latitude. 


\section{Analysis of energy consumption characteristics in typical universities}

Nowadays, American, Japanese, European universities and many other famous universities in the world report to the public about their schools' energy consumption status, energy consumption characteristics and energy saving measures. The paper refers to many universities' green campus construction reports and sustainable campus website ${ }^{[5]}$ and selects Osaka University, Kyoto University, Keio University in Japan, Oxford University in the UK, Yale University, Cornell University, Carnegie Mellon University in the USA as the main objects of the study. It counts the important index such as energy consumption, power consumption, carbon emissions in 2010-2013 and analyzes the energy consumption characteristics

The selected seven universities are located in Asia, America and Europe, all of which are the world famous universities with the world's leading scientific research level. Besides, the universities are the leaders of Green Campus construction and focused on building energy efficiency. Table 1 counts the basic information of the schools.

Table 1 Basic information in universities

\begin{tabular}{cccccccc}
\hline School name & $\begin{array}{c}\text { Osaka } \\
\text { University }\end{array}$ & $\begin{array}{c}\text { Kyoto } \\
\text { University }\end{array}$ & $\begin{array}{c}\text { Keio } \\
\text { University }\end{array}$ & $\begin{array}{c}\text { Oxford } \\
\text { University }\end{array}$ & $\begin{array}{c}\text { Yale } \\
\text { University }\end{array}$ & $\begin{array}{c}\text { Cornell } \\
\text { University }\end{array}$ & $\begin{array}{c}\text { Carnegie Mellon } \\
\text { University }\end{array}$ \\
\hline Latitude ( Degree ) & 34.8 & 34 & 35.4 & 51.46 & 41.15 & 40.43 & 40.2 \\
\hline $\begin{array}{c}\text { Number of people } \\
\text { ( Million people ) }\end{array}$ & 3.53 & 3.48 & 4.60 & 3.30 & 2.90 & 2.15 & 1.83 \\
\hline $\begin{array}{c}\text { Building area } \\
\text { (Million square meters ) }\end{array}$ & 148.43 & 129.32 & 69.67 & 57.72 & 150.50 & 300.00 & - \\
\hline
\end{tabular}

Energy consumption per unit area. Through the statistical summary of annual report, Fig 1 compares the energy consumption per unit area of seven universities in 2010 -2013. Annual energy consumption per unit area includes all of the energy consumption in the form of different energy supply such as electricity, heat, oil and so on.

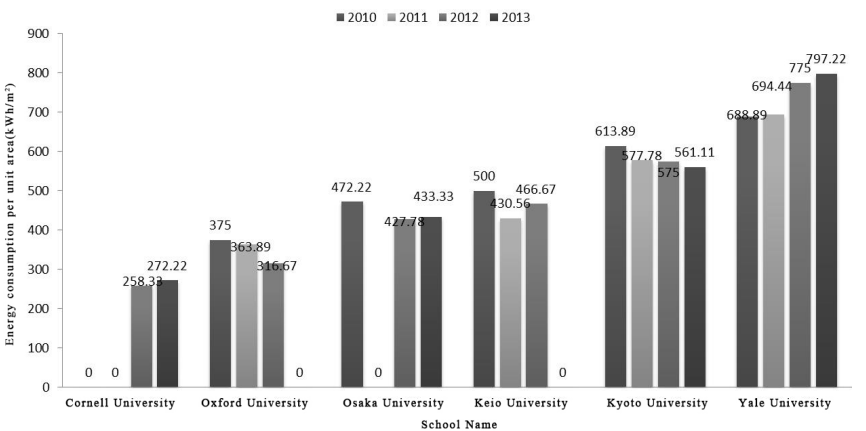

Fig.1 Statistics of energy consumption per unit area in 2010-2013

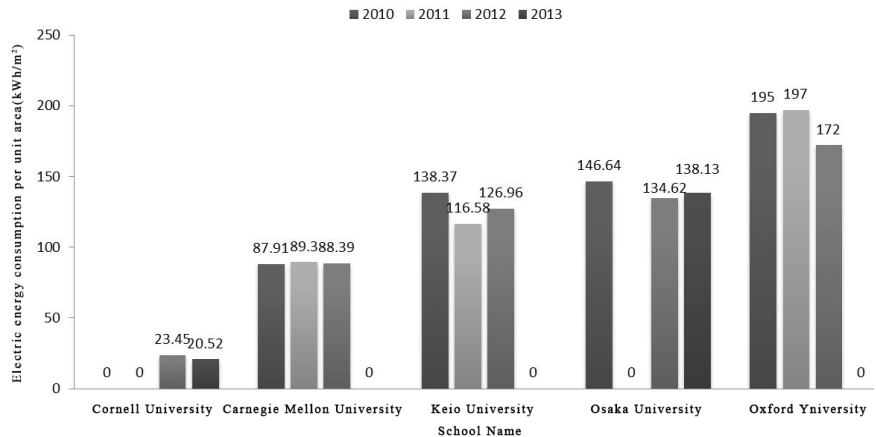

Fig.2 Statistics of electric energy consumption per unit area in 2010-2013

Note: Zero in the figure means lack of the annual data (The same below).

From the figure it can be seen that energy consumption per unit area in the schools is different from $250 \mathrm{kWh} / \mathrm{m}^{2}$ to $800 \mathrm{kWh} / \mathrm{m}^{2}$. Among them, Yale University's energy consumption per unit area is the highest. The average value is $739 \mathrm{kWh} / \mathrm{m}^{2}$. Cornell University's energy consumption per unit area is the lowest. The average value is $265 \mathrm{kWh} / \mathrm{m}^{2}$, a difference of nearly three times than the former. Because of the construction of energy-saving work which is started early, the campus energy consumption in Oxford University on behalf of the European University is relatively low. The average value is $352 \mathrm{kWh} / \mathrm{m}^{2}$. Besides, the difference between three universities in Japan is small, which is maintained from $450 \mathrm{kWh} / \mathrm{m}^{2}$ to $600 \mathrm{kWh} / \mathrm{m}^{2}$.

In addition, each university is actively building a green campus. Through the development trend of the energy consumption data from 2010 to 2013 it can be seen that some of the green campus construction has achieved remarkable results. Energy consumption per unit area of Osaka University, Keio University, Kyoto University and Oxford University campus shows a downward trend year by 
year. Cornell Universities' building energy consumption remains stable. And energy consumption per unit area of Yale University has increased $15.6 \%$ from year 2010 to 2013.

The use of electric energy in universities mainly includes life and research. The types of university disciplines vary widely. Schools of science and engineer have high power consumption because of the experimental equipment. As is shown in Fig 2, the electric energy consumption is small except the Cornell University. Electric energy consumption per unit area of Cornell University is generally in the $80 \mathrm{kWh} / \mathrm{m}^{2}$ above. However, Electrical energy accounts for $7.5 \%$ of the total energy consumption in Cornell University, 30\% in Keio University and Osaka University which are close to, 54\% in Oxford University. Besides, energy use is dominated by natural gas especially in North American university campus. Purchased electricity is used rarely.

Energy consumption per capita. Fig 3 shows the energy consumption per capita of the universities in 2010-2013. The consumption in Yale University is about 40,000kWh/person which is seven times than Oxford University and is largest in all schools. The energy consumption per capita in Keio University and Oxford University which is close to is about 7,000kWh/person. It is the same as Kyoto University and Osaka University which is about $20,000 \mathrm{kWh} /$ person. Cornell University has a large size of the construction area but the number of people in the school is small. So the energy consumption per capita is relatively high which is about $37,000 \mathrm{kWh} /$ person after Yale University.
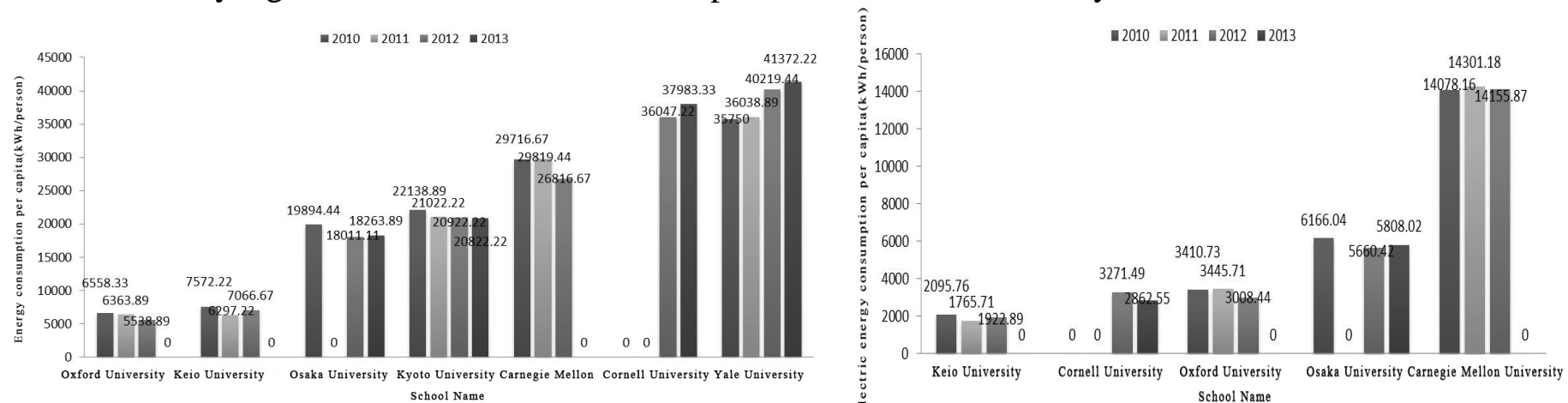

Fig.3 Statistics of energy consumption per capita in 2010-2013

Fig.4 Statistics of electric energy consumption per capita in 2010-2013

Fig.4 reflects the electric energy consumption per capita in 2010-2013, ranging between 2,000 $\mathrm{kWh} /$ person and 14,000kWh/person. The maximum (Carnegie Mellon University) is seven times than the minimum (Keio University). In addition to Carnegie Mellon University, the electric energy consumption per capita is relatively close to $3,400 \mathrm{kWh} /$ person. Osaka University's electric energy consumption per capita is slightly high which is about $6,000 \mathrm{kWh} /$ person. The electric energy consumption per capita of all schools decreases year by year.

Carbon emission per capita. University campus makes carbon emissions accounting and carbon reduction plan as important parts of the construction of Green University. General universities have made five years, ten years or a longer range of carbon reduction plan and develop a detailed implementation to achieve the goal of reducing carbon.

According to the statistics of carbon emission per capita in 2010-2013 (Fig.5), the universities have achieved some results. In recent years, the carbon emission per capita shows a downward trend. Among them, the emission reduction of the Carnegie Mellon University is the most obvious. The carbon emission per capita in 2012 falls by $14.46 \%$ compared with that in 2010 . In addition, because of the universities' climate zone, energy structure, social economy, energy structure, energy equipment and so on, it makes the difference of the carbon emission per capita in different countries. The carbon emission per capita in the European and Asian countries is at a low level which is generally in 1.5-4 t/person, while the American universities' carbon emission per capita is generally higher which is in 6-8 t/person. The carbon emission per capita in Carnegie Mellon University is six times larger than that in Keio University. 


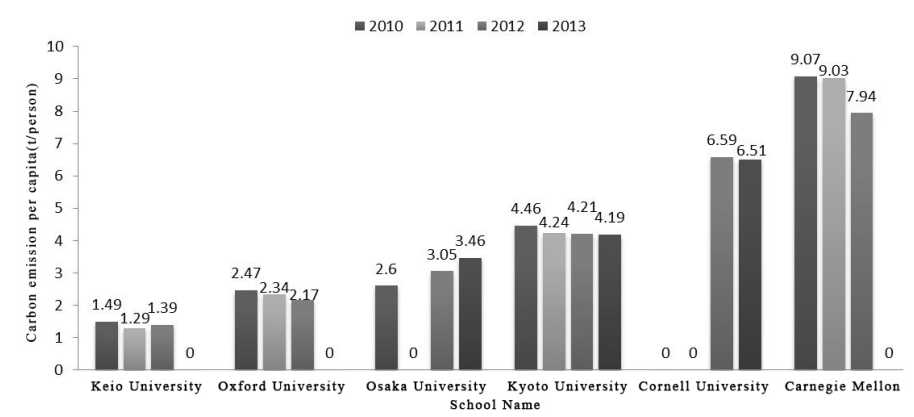

Fig.5 Statistics of carbon emission per capita in 2010-2013

\section{Conclusions}

From the analysis of universities' data it can be seen that the energy consumption gap between different schools is relatively large because of different climate zones, different school types, different building functions and different buildings. To summing up, there are several aspects of the characteristics as following.

(1) The energy consumption per unit area maintains $250-800 \mathrm{kWh} / \mathrm{m}^{2}$. The electric energy consumption per unit area maintains between $80 \mathrm{kWh} / \mathrm{m}^{2}$ and $200 \mathrm{kWh} / \mathrm{m}^{2}$. The distribution of the energy consumption per capita has a large difference. Yale University is about $40,000 \mathrm{kwh} /$ person which is seven times than that of Oxford University. In terms of carbon emission per capita, universities in the European and Asian countries are in a low level which is distributed in $1.5 \mathrm{t} /$ person and universities in American countries maintain in 6-8 t/ person.

(2) The research and practice of building energy saving in universities have started earlier and have formulated the practical and feasible short-term, medium-term and long-term carbon reduction targets and put them into practice. From the 2010-2013 energy consumption statistics, the energy consumption indicators in most universities have a downward trend. Some of universities' energy consumption grows slowly.

(3) The energy consumption index (energy consumption per unit area, electric energy consumption per unit area, energy consumption per capita, electric energy consumption per capita and carbon emission per capita) in Japanese universities is lower than that in other countries and the energy consumption gap between Japanese universities is significantly less than other countries. The energy consumption index of American universities is higher than other countries and the energy consumption gap between the American universities is relatively large.

\section{Acknowledgments}

This research was supported by Project in the National Science \& Technology Pillar Program during the Twelfth Five-year Plan Period (Project name: Evaluation and optimization of building energy consumption system \& Research and demonstration of self-insulation system, Project number: 2011BAJ03B11)

\section{References}

[1] National Bureau of Statistics of China, China Statistical Yearbook in 2008, Beijing, 2009.

[2] Information on http://www.mohurd.gov.cn/zcfg/jsbwj_0/jsbwjjsk.

[3] Min Hee Chunga, Eon $\mathrm{Ku}$ Rhee, Potential opportunities for energy conservation in existing buildings on university campus: A field survey in Korea, Energy and Buildings. 78(2014)176-182.

[4] Tiina Sekkia, Miimu Airaksinenb, Arto Saari, Measured energy consumption of educational buildings in a Finnish city, Energy and Buildings. 87(2015)105-115.

[5] Information on http://www.cgun.org/news.aspx?info_lb=121\&flag=116. 